\title{
Use of Microscopic FT-IR/DSC Combined System for the Study of Glass Transition Temperatures of Polymers
}

\author{
Shan-Yang Lin, ${ }^{*}$ Chao-Ming LiAO, and Run-Chu Liang \\ Biopharmaceutics Laboratory, Department of Medical Research, \\ Veterans General Hospital-Taipei, \\ Taipei, Republic of China
}

(Received August 26, 1994)

KEY WORDS Glass Transition / Differential Scanning Calorimetry /
Microscopic FT-IR / DSC System / Polymers /

Polymers exhibit significantly different physical and mechanical properties near glass transition $\left(T_{\mathrm{g}}\right)$ temperature. ${ }^{1,2}$ Since glass transition is related to change in the molecular motion of polymers, the infrared (IR) spectrum in the transition regions probably provides certain information on vibrational motion in relation to polymer transition. Hannon et al. suggest that IR spectroscopy is a sensitive and unique means for determining transition behavior in polymers, but sample preparation and the sample cell designed for $T_{\mathrm{g}}$ determination seem to be complicated. ${ }^{3}$ Lin et al. recently used newly-developed microscopic Fourier transform infrared (FT-IR) spectroscopy equipped with differential scanning calorimetry (DSC) to study simultaneously the thermal behavior and structural changes of samples such as drug polymorphs, porcine stratum corneum, silicone elastomer, and encapsulated squil oil. ${ }^{4-8}$ This newly-designed system is a simple, quick, and powerful apparatus, in which the sample is only sealed within a $\mathrm{KBr}$ disc and set on a DSC microscopy cell. Since chain motion is the major mechanism in the transition state, $T_{\mathrm{g}}$ of a sample may be easily predicted by this microscopic FT-IR/DSC system. The purpose of this

\footnotetext{
* To whom correspondence should be addressed.
}

report is to show experimentally the usefulness of the newly-developed microscopic FTIR/DSC combined system by exploring the glass transition temperature of polymers in a short period of time, instead of other known techniques.

\section{EXPERIMENTAL}

\section{Materials}

Polystyrene (PS, $\left.M_{w}, 130000\right)$, poly(vinyl chloride) (PVC, $\left.M_{w}, 70000\right)$ and poly(ethylene terephthalate) (PET, $\left.M_{w}, 17500\right)$ were kindly supplied from Formorsa Chem. \& Filbre Co. (Taipei, ROC), Taiwan Plastic Ltd. (Taipei, ROC) and Forest Textile Ltd. (Hsin Chu, Taiwan, ROC), respectively. Eudragit L-100 (copolymer of methacrylic acid and methylmethacrylate, $M_{w}, 135000$ ) and poly(lactic acid) (PLA, $M_{w}, 2500$ ) were obtained from Röhm Pharma (Darmstadt, Germany) and Kokusan Chem. Works, (Tokyo, Japan).

\section{Differential Scanning Calorimetry}

The thermal behavior of samples was examined in open aluminium pans using a differential scanning calorimetry (DSC-910, TA Instruments. Inc., USA) at a scanning 
rate of 5 or $10^{\circ} \mathrm{C} \mathrm{min}^{-1}$ under $\mathrm{N}_{2}$ gas stream. The samples of PLA and Eudragit L-100 were heated to 150 and $180^{\circ} \mathrm{C}$, respectively and held at constant temperature for $5 \mathrm{~min}$, and then rapidly cooled with ice to obtain quenched samples. The quenched samples and other native samples were measured by a DSC analyser. $T_{\mathrm{g}}$ were taken from an inflexion point on the DSC curves. ${ }^{9}$

\section{Microscopic FT-IR/DSC Combined System}

Polymers were used without further treatment. The samples were sealed between $\mathrm{KBr}$ discs $(6 \mathrm{~mm})$ by hydraulic pressing. The $\mathrm{KBr}$ disc was placed in the DSC microscopy cell (FP 84, Mettler, Switzerland) and set in the FT-IR microscopic spectrometer (Micro FTIR-200, Jasco, Japan) equipped with an MCT detector. The position and focus of the sample were adjusted by microscope. The temperature of the DSC microscopy cell was controlled with a central processor (FT80HT, Mettler, Switzerland). During each experiment, the sample disc was equilibrated to the starting temperature for $3 \mathrm{~min}$ and then heated. The heating rate of the DSC microscopy cell was set at 5 or $10^{\circ} \mathrm{C} \mathrm{min}^{-1}$. A 3-dimensional plot and changes in intensity of the specified peaks were studied by Data Processing Program. ${ }^{4-8} T_{\mathrm{g}}$ was taken from a change in slope or midpoint of the descending graphs of peak absorption $v s$. temperature. $^{3}$

\section{RESULTS AND DISCUSSION}

In this study, two types of profiles on the plot of peak absorption vs. temperature were obtained. The first typical profile is a slow descending curve with temperature; the other profile is a descending curve with dramatic change.

Figure 1 shows three-dimensional plots of FT-IR spectra of the PS sample in the region from 1400 to $1700 \mathrm{~cm}^{-1}$ when temperature increases from 28 to $200^{\circ} \mathrm{C}$. DSC curve and IR absorbances at 1601,1493 , and $1454 \mathrm{~cm}^{-1}$ of
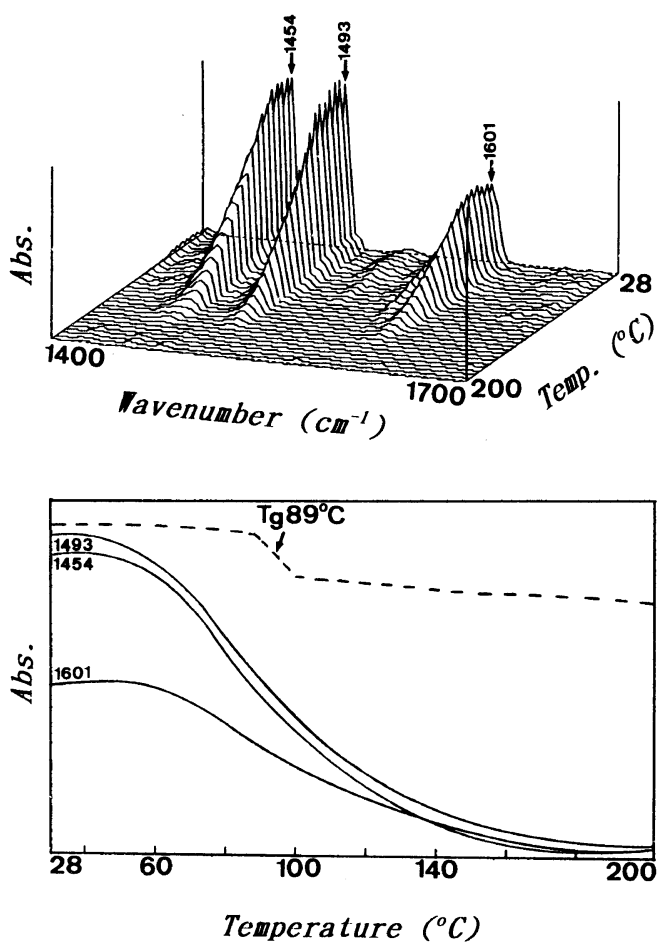

Figure 1. Three-dimensional plots of IR spectra of polystyrene, DSC thermogram and absorbance of the specified bands as a function of temperature.

the PS sample are also plotted as a function of temperature in Figure 1. Apparently, the peak intensities of the bands at 1601, 1493, and $1454 \mathrm{~cm}^{-1}$ gradually decreased with increasing temperature and then disappeared. $T_{\mathrm{g}}$ of PS is about $89^{\circ} \mathrm{C}$ obtained from the inflexion point of DSC thermogram, which was near $85^{\circ} \mathrm{C}$ of the literature value, as shown in Table $\mathrm{I}^{10}$ When the $T_{\mathrm{g}}$ point was taken from the midpoint of the descending graph of peak absorption $v s$. temperature, $T_{\mathrm{g}}$ for 1601,1493 , and $1454 \mathrm{~cm}^{-1}$ absorption bands were 98,92 , and $89^{\circ} \mathrm{C}$, respectively. $T_{\mathrm{g}}$ of the $1454 \mathrm{~cm}^{-1}$ band was close to $T_{\mathrm{g}}$ in the DSC curve, suggesting the $1454 \mathrm{~cm}^{-1}$ band to be a sensitive band corresponding to conformational change in PS. This is consistent with the report in which different absorption peaks showed different $T_{\mathrm{g}}{ }^{11}$ This might be attributed to the fact that these transitions are associated with change in 

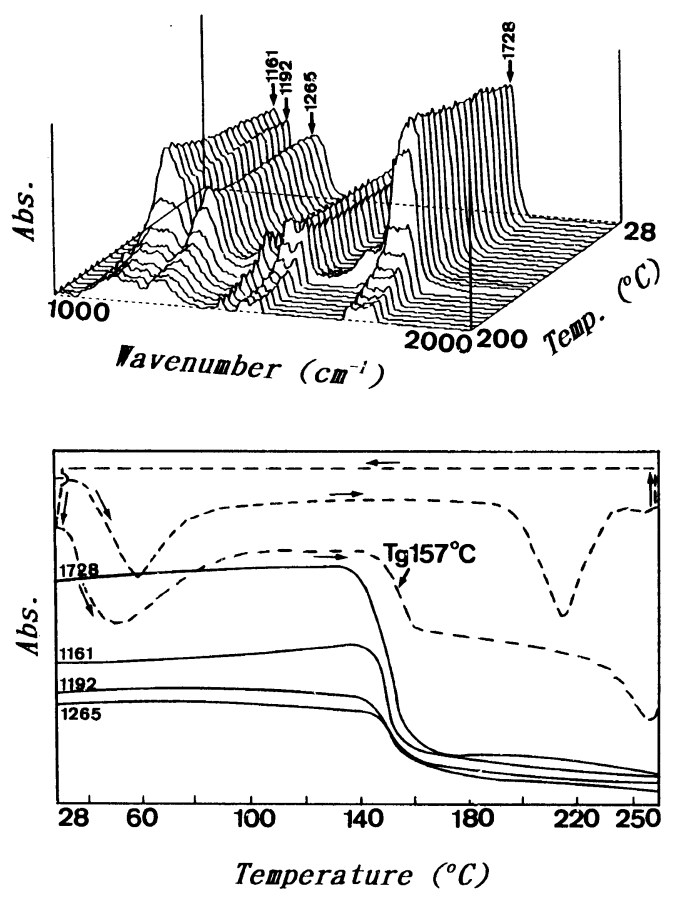

the dipole moment. ${ }^{2,12}$ At the glass transition temperature, the freedom of polymer molecules might increase to allow some intramolecular rotations and/or molecular motion of main chain or side chain, ${ }^{2}$ resulting in change in the intensity of the IR band. The IR absorption spectra for the PET and PLA samples also exhibited slow decending profiles, which is in good agreement with the observations of PS. It should be noted that $T_{\mathrm{g}}$ of the PLA by DSC was obtained from the quenched sample, but the microscopic FT-IR/DSC system might directly obtain $T_{\mathrm{g}}$ without further quenching process.

Figure 2 shows 3-dimensional IR plots, DSC thermogram and absorbance of the 1728, 1265, 1192 , and $1161 \mathrm{~cm}^{-1}$ bands as a function of

Figure 2. Three-dimensional plots of IR spectra of Eudrgait L-100, DSC thermogram and absorbance of specified bands as a function of temperature.

Table I. Glass transition temperatures of polymers determined by DSC and the microscopic FT-IR/DSC system ${ }^{\text {a }}$

\begin{tabular}{|c|c|c|c|c|}
\hline \multirow{2}{*}{ Samples } & \multicolumn{2}{|c|}{ DSC } & \multirow{2}{*}{$\begin{array}{c}\text { Microscopic } \\
\text { FT-IR/DSC system }\end{array}$} & \multirow{2}{*}{$\begin{array}{l}\text { Value of } \\
\text { literature }\end{array}$} \\
\hline & $\begin{array}{c}\text { Direct } \\
\text { determination }\end{array}$ & $\begin{array}{c}\text { Indirect } \\
\text { determination }\end{array}$ & & \\
\hline Polystyrene & $89^{\circ} \mathrm{C}$ & - & $\begin{array}{ll}1601 \mathrm{~cm}^{-1}: & 98^{\circ} \mathrm{C} \\
1493 \mathrm{~cm}^{-1}: & 92^{\circ} \mathrm{C} \\
1454 \mathrm{~cm}^{-1}: & 89^{\circ} \mathrm{C}\end{array}$ & $85^{\circ} \mathrm{C}$ \\
\hline Poly(ethylene terephthalate) & $77^{\circ} \mathrm{C}$ & - & $\begin{array}{ll}1720 \mathrm{~cm}^{-1}: & 78^{\circ} \mathrm{C} \\
1408 \mathrm{~cm}^{-1}: & 77^{\circ} \mathrm{C} \\
1242 \mathrm{~cm}^{-1}: & 79^{\circ} \mathrm{C} \\
1095 \mathrm{~cm}^{-1}: & 80^{\circ} \mathrm{C}\end{array}$ & $68^{\circ} \mathrm{C}$ \\
\hline Polylactic acid & - & $\begin{array}{c}47^{\circ} \mathrm{C} \\
\left(150^{\circ} \mathrm{C}\right)\end{array}$ & $\begin{array}{ll}1755 \mathrm{~cm}^{-1}: & 56^{\circ} \mathrm{C} \\
1450 \mathrm{~cm}^{-1}: & 71^{\circ} \mathrm{C} \\
1188 \mathrm{~cm}^{-1}: & 65^{\circ} \mathrm{C} \\
1095 \mathrm{~cm}^{-1}: & 68^{\circ} \mathrm{C}\end{array}$ & $44^{\circ} \mathrm{C}$ \\
\hline Eudragit L- $100^{\mathrm{b}}$ & - & $\begin{array}{c}157^{\circ} \mathrm{C} \\
\left(200^{\circ} \mathrm{C}\right)\end{array}$ & $\begin{array}{l}1728 \mathrm{~cm}^{-1}: 148^{\circ} \mathrm{C} \\
1245 \mathrm{~cm}^{-1}: 150^{\circ} \mathrm{C} \\
1192 \mathrm{~cm}^{-1}: 150^{\circ} \mathrm{C} \\
1161 \mathrm{~cm}^{-1}: 150^{\circ} \mathrm{C}\end{array}$ & $160^{\circ} \mathrm{C}$ \\
\hline Poly(vinyl chloride) & $88^{\circ} \mathrm{C}$ & - & $\begin{aligned} 1435 \mathrm{~cm}^{-1}: & 95^{\circ} \mathrm{C} \\
1331 \mathrm{~cm}^{-1}: & 97^{\circ} \mathrm{C} \\
1250 \mathrm{~cm}^{-1}: & 94^{\circ} \mathrm{C} \\
972 \mathrm{~cm}^{-1}: & 97^{\circ} \mathrm{C}\end{aligned}$ & $81^{\circ} \mathrm{C}$ \\
\hline
\end{tabular}

a Value in parentheses: isothermal temperature for $5 \mathrm{~min} .{ }^{\mathrm{b}}$ Copolymer of methacrylic acid and methyl methacrylate. 
temperature for the Eudragit L. It clearly indicates that all the IR spectra of the Eudragit $\mathrm{L}$ in the 3-dimensional plot change suddenly at $140-160^{\circ} \mathrm{C}$, and then disappear as temperature increases. This abrupt change in the profile of absorbance vs. temperature was more apparent beyond $140^{\circ} \mathrm{C}$. The dramatic change in IR absorbance might be due to glass transition of the Eudragit $\mathrm{L}$. The $T_{\mathrm{g}}$ point of the quenched Eudragit L sample on the DSC curve was $157^{\circ} \mathrm{C}$, while $T_{\mathrm{g}}$ obtained from the midpoint of the descending curve for above four specified peaks was within $148-150^{\circ} \mathrm{C}$ (Table I). The two different methods might explain these different $T_{\mathrm{g}}$. However, these values are approximately equal. PVC also showed similar results. An abrupt change in temperature was within $80-100^{\circ} \mathrm{C}$ in the plot of the absorbance $v s$. temperature. This abrupt change at $94-97^{\circ} \mathrm{C}$ for four specified peaks $\left(1435,1331,1250\right.$, and $\left.972 \mathrm{~cm}^{-1}\right)$ was approximately the $T_{\mathrm{g}}$ of the PVC sample determined by DSC. ${ }^{10}$

In conclusion, the newly-developed microscopic FT-IR/DSC system seems to be a simple, quick and powerful means for analyzing glass transition temperatures of polymers.

\section{REFERENCES AND NOTES}

1. M. S. Ali and R. P. Sheldon, J. Appl. Polym. Sci., 14, 2619 (1970).

2. L. H. Sperling, Ed., "Introduction to Physical Polymer Science," 2nd ed, John Wiley \& Sons, New York, N.Y., 1993, p 303.

3. M. J. Hannon and J. L. Koenig, J. Polym. Sci., A, 7, 1085 (1969).

4. S. Y. Lin, J. Pharm. Sci., 81, 572 (1992).

5. S. Y. Tsai, S. C. Kuo, and S. Y. Lin, J. Pharm. Sci., 82, 1250 (1993).

6. S. Y. Lin, R. C. Liang, and T. C. Lin, J. Chin. Chem. Soc., 41, 425 (1994).

7. S. Y. Lin, W. J. Tsay, Y. L. Chen, and C. J. Lee, J. Control. Res., 31, 277 (1994).

8. S. Y. Lin, L. S. Hwang, and C. C. Lin, J. Microencap., in press (1995).

9. J. F. Rabek, Ed., "Experimental Methods in Polymer Chemistry," John Wiley \& Sons Ltd., New York, N.Y., 1980, p 549.

10. J. Brandrup and E. H. Immergut, Ed., "Polymer Handbook," 2nd ed, Wiley-Interscience, London, 1975.

11. K. Ogura, S. Kawamura, and H. Sobue, Macromolecules, 4, 79 (1971).

12. A. Aihara, "Bunshi Kagaku Koza," Vol. 10, Kyoritsu, Tokyo, 1967, p 169. 